\title{
Non Atrial Fibrillation related Central Retinal Artery Occlusion (CRAO) in Hyperthyroidism: A Case Report
}

\author{
Dr. Wawhal $M^{1}$, Dr. Mogal $V^{2}$, Dr. Dalvi $V^{3}$, Dr. Sanap $S^{4}$, Dr. Rathi $A^{5}$ \\ ${ }^{1}$ Dr. Mahendra Wawhal, Senior Consulltant and Associate Professor, MD, ${ }^{2}$ Dr.Vajed Mogal, Chief Resident in the \\ Department of Medicine, ${ }^{3}$ Dr.Vishal Dalvi, Chief Resident in the Department of Medicine, ${ }^{4}$ Dr.Sandeep Sanap, Chief \\ Resident in the Department of Medicine, ${ }^{5}$ Dr. Amit Rathi, Junior Resident in the Department of Medicine all are department \\ of medicine and affiliated with Mahatma Gandhi Mission's Medical College and Hospital, CIDCO, N-6, Aurangabad, \\ Maharashtra, India.
}

Address for correspondence: Dr.Vajed Mogal, Email: drvajedmogal@gmail.com

\begin{abstract}
We report a case of non AF related Central retinal artery occlusion (CRAO) (Stroke) in untreated \& uncontrolled hyperthyroidism. CRAO can be considered as an ocular analogue of stroke or an ocular equivalent of acute myocardial infarction. Generally hyperthyroidism is associated with Stroke (CRAO) because of atrial fibrillation. However, we report a case of uncontrolled hyperthyroidism with CRAO in the absence of atrial fibrillation. It is with an intent to highlight the fact that a hyperthyroid state is not only complicated by AF, but even hyperthyroidism in itself is a potential risk factor in the causation of stroke.We came across only one case report of ischaemic stroke in a hyperthyroid patient without AF. We could not find any case report of hyperthyroidism with AF related CRAO in literature. Hence we report first case of non $\mathrm{AF}$ related CRAO in hyperthyroidism \& perhaps second case report of non AF related stroke in hyperthyroidism in literature so far. An uncontrolled hyperthyroid state is tantamount to a sustained inflammatory state that results in endothelial dysfunction by causing hypercoagulable state culminating in a small calibre vessel blockage.
\end{abstract}

Keywords: Atrial fibrillation (AF), Central Retinal Artery Occlusion (CRAO), Hyperthyroidism.

\section{Introduction}

Central retinal artery occlusion (CRAO) is a disease of the eye where the flow of blood through the central retinal artery is blocked (occluded). Central retinal artery is a branch of ophthalmic artery which causes sudden, acute, and painless loss of vision in one eye [2]. The most common cause for CRAO is carotid artery atherosclerosis [3]. Hyperthyroidism is a common endocrinal disorder affecting $0.5 \%$ to $2 \%$ of the population and young adults comprise a sufficient proportion of disorders [4,5]. We came across only one case report of ischaemic stroke in a hyperthyroid patient without AF [1]. We could not find any case report of hyperthyroidism with $\mathrm{AF}$ related $\mathrm{CRAO}$ in literature. Hence we report first case of non AF related CRAO in hyperthyroidism \& perhaps second case report of non $\mathrm{AF}$ related stroke in hyperthyroidism in literature so far.

Manuscript received: $4^{\text {th }}$ Dec 2014

Reviewed: $6^{\text {th }}$ Dec 2014

Author Corrected; $17^{\text {th }}$ Dec 2014

Accepted for Publication: $2^{\text {nd }}$ Jan 2015

\section{Case Report}

A 22 years young male diagnosed by ophthalmic surgeon as central retinal artery occlusion (CRAO) was referred to us for evaluation and further management. He presented with sudden, acute, painless loss of vision in right eye since last 24 hours.

There was no headache, vomiting, convulsion or any neurological deficit. He was diagnosed case of hyperthyroidism since 3 years, took treatment for 3 months only and was not on any treatment since then.

On examination, he was conscious, oriented, afebrile with pulse rate of $110 / \mathrm{min}$, blood pressure of 130/70 $\mathrm{mmHg}$. His peripheral pulsations were well felt, no carotid bruit was heard.

He had all deep tendon reflexes brisk on examination. Rest of the examination was unremarkable. 
He had no addiction. Other personal history was insignificant. He had no history of any medications or drugs. His family history was insignificant. His thyroid function tests showed rise in free T3 \& T4 with suppressed serum TSH of 0.0004 suggestive of frank hyperthyroidism.

His kidney function tests, liver function tests \& lipid profile were normal. His coagulation profile was absolutely normal. His Sr. ANA, ds DNA, and Anti phospholipid antibodies workup was negative \& other autoimmune markers were also negative with an ESR of $40 \mathrm{~mm}$.

Also his ANCA panel was negative, including both myeloperoxidase and perinuclear antibodies. Coagulation profile including Protein $\mathrm{C}$, Protein S and antithrombin III were normal. His 2D echo was normal. MRI brain with angiogram too was normal (Fig 1).
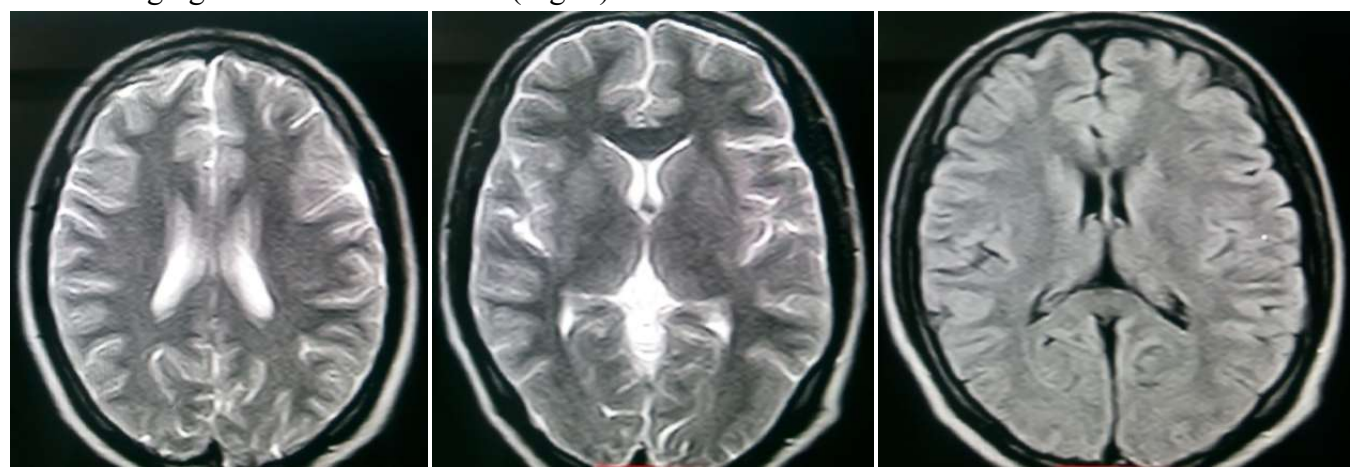

Fig 1: MRI Brain reveals Normal Study

\section{Discussion}

We have reported a case which shows that hyperthyroidism itself can cause stroke (central retinal artery occlusion) in the absence of atrial fibrillation.

Retinal artery occlusion (RAO) is a blockade in one of the small arteries that carry blood to the retina. Retinal arteries may become blocked when a blood clot is lodged in the arteries. Clot may travel from other parts of the body and block an artery in the retina. The most common sources of emboli are the heart and carotid artery in the neck i.e. cardioembolism or artery to artery embolism respectively [6]. The retinal artery occlusion may last for only a few seconds or minutes, or it may be permanant. Retinal artery occlusion (RAO) is mostly seen in the elderly with clinical findings suggestive of atheromatous emboli [7]. Von Graefe in 1859 described CRAO in a patient of endocarditis and multiple systemic emboli [8].

International Journal of Medical Research and Review
Carotid doppler study was also normal. Holter monitoring was done which was reported as normal. In view of all normal reports, except uncontrolled hyperthyroid state, the patient was treated as a case of primary hyperthyroidism with CRAO.

He was put on antithyroid treatment; aspirin \& clopidogrel (Dual antiplatelet), statins were started immediately and low molecular weight heparin was given for 5 days. Immediately on $2^{\text {nd }}$ day, interventional radiologist posted him for intraarterial thrombolysis but there was no improvement of vision.

Patient was under follow up, his heart rate was normal. He was put on antithyroid treatment, aspirin and low dose statin therapy. In our case there was CRAO in an uncontrolled state of hyperthyroidism in absence of atrial fibrillation. 
fibrinolysis and atherogensis induced by lipoprotein-A may play a role in the pathophysiology of CRAO [17]. A study by Brown and associates[8] found $29.6 \%$ patients with coagulation disorder while in a study by Greven et al[13]. 9\% patients had coagulation disorders. A study by Suvajach et al [18], showed that ocular arterial and venous occlusions were common in patients with antiphospholipid syndrome. RAO secondary to vasculitis has been encountered in many conditions. A study by $\mathrm{Au}$ and O'doy has shown presence of retinal artery occlusion in $4.5 \%$ patients of systemic lupus erythematosus (SLE) [19]. There is no proven treatment for vision loss that involves the whole eye (RAO), unless it is caused by an underlying illness that can be treated. Although some studies suggested that there was no correlation between outcome and time to treatment [20], 6-12 hr of time window is generally accepted [21-23]. Visual prognosis is often poor when thrombolysis is administered more than $20 \mathrm{hr}$ after CRAO [21-25].

Hyperthyroidism is well known to be associated with an increased risk of atrial fibrillation among the people aged 60 years order [26], and there is a high risk for cardioembolic stroke in hyperthyroidism patients with atrial fibrillation [27]. The mechanism of thyroid hormone - induced dysfunction is multifactorial. The heart rate increases due to increased sinoatrial activity, a lower threshhold for atrial activity and shortened atrial repolarization [28,29]. These last 2 factors also create a favourable substrate for the generation of $\mathrm{AF}$, and a similar effect on ventricular myocardium has been linked with ventricular arrythmias [30]. Volume preload increases due to activation of renin angiotensin system [31]. Contractility increases due to increased metabolic demand and the direct effect of triiodothyronine on cardiac muscle [32] and systemic vascular resistance decreases because of triiodothyronine - induced peripheral vasodilation [33].

Thyroid hormone has numerous effects on coagulation. Studies indicate that hyperthyroidism is associated with increased thrombotic risk [34]. Coagulation abnormalities such as shortened activated partial thromboplastin time, increased fibrinogen levels and increased factor VIII and factor X activity [35] and clinical sequalae such as stroke[36] are seen frequently in patients in sinus rhythm with thyrotoxicosis. Hyperthyroidism is associated with prominent cardiovasular events such as systolic hypertension, which may contribute to vascular morbidity and mortality [37]. Increased stiffness and intima media thickness, the two indices of atherosclerosis, are found in the carotid artery in patent with hyperthyroidism, which are attributable to harmful effects of increased cardiac output and widened pulse pressure[38,39]. Hypercoagulable state observed in hyperthyroidism, includes increase in blood volume, increased levels of acute phase reactants, thrombin and fibrinogen activity [40] An increase in Van Willebrand factor level in patient with hyperthyroidism indicates endothelial dysfunction and is associated with enhanced platelet plug formation $[41,42]$.

Atrial fibrillation is a cardiac complication of hyperthyroidism, occurring in an estimated $10 \%$ to $25 \%$ of overtly hyperthyroid patients. The prevalence of AF in both population increases with age [43]. It is more common in men than in women [44]. High normal thyroid levels or subclinical hyperthyroidism is also associated with an increased risk of developing AF [45].

In patients with hyperthyroidism, AF is frequently of acute onset and will spontaneously revert to sinus thythm without associated side effects often referred to as silent transient $\mathrm{AF}$ of thyrotoxicosis. The prevalence of AF thyrotoxicosis in patients with $\mathrm{AF}$ is $2 \%$ to $5 \%$ [46]. In subclinical hyperthyroidism with serum TSH level $<0.1$ MIU/L, the incidence of AF is increased, and in overt hyperthyroidism, cardioembolic stroke is clearly associated to thyrotoxic AF.

According to the trial of Org. 10172 an Acute stroke treatment criteria,[47] previous studies have found that strokes of other determined etiologies explained $\sim 25 \%$ of ischamic strokes in young people, including dissection, antiphospholipid syndrome, moyamoya disease, SLE, migraine related stroke, and coagulopathy[48,49]. A study by shoe et al [50]. suggested that thyrotoxic patients (without AF), as compared to euthyroid individuals, are at increased risk for ischemic strokes with a hazard ratio of 1.44.

\section{Conclusion}

Generally there is high risk of stroke in hyperthyroid patients with atrial fibrillation.However in our case report,hyperthyroidism itself caused stroke(CRAO) without occurrence of atrial fibrillation. There were no other acquired risk factors of stroke or inherited risk factor in our case. Hence, it appears that hyperthyroidism itself by the way of continuous and sustained inflammatory stress, inducement of procoagulation state and endothelial dysfunction may havr caused small caliber artery i.e. CRAO stroke. Very few cases of stroke $\&$ lesser even of CRAO cases are reported in literature in 
hyperthyroidism in absence of AF. We report this case to highlight the fact that uncontrolled hyperthyroidisim even without atrial fibrillation can cause stroke of small caliber artery like CRAO.

Funding: Nil,

Permission from IRB: Yes

Conflicts of interest: The authors report no conflicts of interest

\section{References}

1. Onwelekwe I, Eze C, Ekenzze O. Ischaemic Stroke in hyperthyroidism without cardiac arrhythmia : A Case report from South east Nigeria. Niger J Med 2012;21(4):458-61.

2. Kunimoto.Vascular diseases of the retina, AT Still University SOMA, 2012.http://en.wikipedia.org/wiki/Central_retinal_artery _occlusion. 21-12-2014.

3. Central and branch retinal artery occlusion. Update.com. Mar 14,2012.

4. Hollowell JG, Staehling NW, Flanders WD, Hannon WH, Gunter EW, Spencer CA, Braverman LE. Serum TSH, T4, and thyroid antibodies in the United States population (1988 to 1994): National Health and Nutrition Examination Survey (NHANES III). J Clin Endocrinol Metab. 2002 Feb;87(2):489-99.

5. Flynn RWV, MacDonald TM, Morris AD, Jung RT, Leese GP. The thyroid epidemiology, audit, and research study: thyroid dysfunction in the general population. J Clin Endocrino Metab. 2004;89:3879 -3884.

6. Retianal artery occlusion: Medline Plus Medical Encyclopedia.

http://www.nIm.nih.gov/medlineplus/ency/article/00102 8.htm

7. Kollarits CR, Lubow M, Hissong SL. Retinal Strokes: I: Incidence of carotid atheromata. JAMA 1972;222:1273-5.

8. Von Graefe A. Ueber Embolie der Arteria centralis retinae als Ursache plotzlicher Erblindung. Albrecht von Graefes Arch Ophthalmol 1859;5:136-57.

9. Brown GC, Magargal LE, Shields JA, Goldberg RE, Walsh PN. Retinal arterial obstruction in children and young adults.Ophthalmology 1981;88:18-25.

International Journal of Medical Research and Review
10. Clarke R, Daly L, Robinson $\mathrm{K}$ et al. Hyperhomocysteinemia: An Independent risk factor for vascular disease. N Engl J Med 1991;324:1149.

11. Dan L. Longo et al. Harrison's Principles of Internal Medicine, 18th Edition. New York. The McGraw Hill Companies, Inc. 2011.3274-80.

12. Rumelt S, Dorenboim Y, Rehany U. Aggressive systematic treatment for central retinal artery occlusion. Am J Ophthalmol 1999;128:733-8.

13. Greven CM, Slusher MM, Weaver RG. Retinal arterial occlusion in young adults. Am J Ophthalmol 1995;120:776-83.

14. Brown GC, Magargal LE. Central retinal artery occlusion and visualacuity. Ophthalmology 1982;89:149.

15. Karjalainen K. Occlusion of the central retinal artery and retinal branch arterioles: A clinical, tonographic and fluorescein angiographic study of 175 patients. Acta Ophthalmol 1971;109:1-95.

16. Gronemeyer A, Arsène S, Le Lez ML, Rateau J. Central retinal artery occlusion or branch retinal artery occlusion in the young associated with high lipoprotein (a) levels. J Fr Ophtalmol 2002;25:727-30.

17. Murata M, Saito T, Takahashi S, Ichinose A. Plasma lipoprotein(a) levels are high in patients with central retinal artery occlusion.Thromb Res 1998;91:169-75.

18. Suvajac G, Stojanovich L, Milenkovich S. Ocular manifestations in antiphospholipid syndrome. Autoimmun Rev 2007;6:409-14.

19. Au A, O’Day J. Review of severe vaso-occlusive retinopathy in systemic lupus erythematosus and the antiphospholipid syndrome: Associations, visual outcomes, complications and treatment. Clin Exp Ophthalmol 2004;32:87-100.

20. Beatty $\mathrm{S}, \mathrm{Au}$ Eong KG. Local intra-arterial fibrinolysis for acute occlusion of the central retinal artery: a meta-analysis of the published data. $\mathrm{Br} \mathrm{J}$ Ophthalmol. 2000;84:914-916.

21. Plant GT, Landau K. Thrombolysis for central retinal artery occlusion. J Neurol Neurosurg Psychiatry.2005;76:160-161.

Available online at: www.ijmrr.in 124 | P a g e 
22. Hayreh SS. Retinal arterial occlusion with LIF using rTPA. Ophthalmology. 1999;106:1236-1239.

23. Schumacher M, Schmidt D, Wakhloo AK. Intraarterial fibrinolytic therapy in central retinal artery occlusion. Neuroradiology. 1993;35:600-605.

24. Rumelt S, Brown GC. Update on treatment of retinal arterial occlusions. Curr Opin Ophthalmol.2003;14:139141.

25. Biousse V, Calvetti O, Bruce BB, Newman NJ. Thrombolysis for central retinal artery occlusion. $\mathrm{J}$ Neuroophthalmol. 2007;27:215-230.

26. Frost L, Vestergaard P, Mosekilde L. Hyperthyroidism and risk of atrial fibrillation or flutter: a population-based study. Arch Intern Med. 2004;164:1675-1678.

27. Squizzato A, Gerdes VEA, Brandjes DP, Bullar HR, Stam J. Thyroid diseases and cerebrovascular disease. Stroke. 2005;36:2302-2310.

28. Cacciatori V, Bellavere F, Pezzarossa A, Dellera A, Gemma ML, Thomaseth K, et al. Power spectral analysis of heart rate in hyperthyroidism. J Clin Endocrinol Metab 1996;81(8):2828-35.

29. Bielecka-Dabrowa A, Mikhailidis DP, Rysz J, Banach M. The mechanisms of atrial fibrillation in hyperthyroidism. Thyroid Res 2009;2(1):4.

30. Nadkarni PJ, Sharma M, Zinsmeister B, Wartofsky L, Burman KD. Thyrotoxicosis-induced ventricular arrhythmias. Thyroid 2008;18(10):1111-4.

31. Resnick LM, Laragh JH. Plasma renin activity in syndromes of thyroid hormone excess and deficiency. Life Sci 1982;30(7-8):585-6.

32. Polikar R, Burger AG, Scherrer U, Nicod P. The thyroid and the heart. Circulation 1993;87(5):1435-41.

33. Ojamaa K, Klemperer JD, Klein I. Acute effects of thyroid hormone on vascular smooth muscle. Thyroid 1996;6(5):505-12.

34. Franchini M, Montagnana M, Manzato F, Vescovi PP. Thyroid dysfunction and hemostasis: an issue still unresolved. Semin Thromb Hemost 2009;35(3):288-94.
35. Erem C, Ersoz HO, Karti SS, Ukinc K, Hacihasanoglu A, Deger O, Telatar M. Blood coagulation and fibrinolysis in patients with hyperthyroidism. J Endocrinol Invest 2002;25(4):34550.

36. Petersen P, Hansen JM. Stroke in thyrotoxicosis with atrial fibrillation. Stroke 1988;19(1):15-8.

37. Osman F, Franklyn JA, Holder RL, Sheppard MC, Gammage MD.Cardiovascular manifestations of hyperthyroidism before and after antithyroid therapy: a matched case-control study. J Am Coll Cardiol. 2007;49:71-81.

38. Inaba M, Henmi Y, Kumeda Y, Ueda M, Nagata M, Emoto $\mathrm{M}$, Ishikawa $\mathrm{T}$, Ishimura $\mathrm{E}$, Nishizawa $\mathrm{Y}$. Increased stiffness in common carotid artery in hyperthyroid Graves' disease patients. Biomed Pharmacother. 2002;56:241-246.

39. Volzke H, Robinson DM, Schminke U, Ludemann J, Rettig R, Felix SB,Kessler C, John U, Meng W. Thyroid function and carotid wall thickness.J Clin Endocrinol Metab. 2004;89:2145-2149.

40. Erem C. Coagulation and fibrinolysis in thyroid dysfunction. Endocrinology.2009;36:110 -118.

41. Erem C, Ersoz HO, Karti SS, Ukinc K, Hacihasanoglu A, Deger O, Telatar M. Blood coagulation and fibrinolysis in patients with hyperthyroidism. J Endocrinol Invest. 2002;25:345-350.

42. Homoncik M, Gessl A, Ferlitsch A, Jilma B, Vierhapper H. Altered platelet plug formation in hyperthyroidism and hypothyroidism. J Clin Endocrinol Metab. 2007;92:3006-3012.

43. Ostrander LD Jr, Brandt RL, Kjelsberg MO, Epstein FH. Electrocardiographic findings among the adult population of a total natural community, Tecumseh, Michigan. Circulation 1965;31:888-98.

44. Petersen P. Thromboembolic complications in atrial fibrillation. Stroke.1990;21:4-13.

45. Heeringa J, Hoogendoorn EH, van der Deure WM, Hofman A, Peeters RP, Hop WC, et al. High-normal thyroid function and risk of atrial fibrillation: the Rotterdam study. Arch Intern Med 2008;168(20):221924

Available online at: www.ijmrr.in 125 | P a g e 
46. Petersen P, Boysen G, Godtfredsen J, Andersen ED, Andersen B.Placebo-controlled, randomised trial of warfarin and aspirin for prevention of thromboembolic complications in chronic atrial fibrillation.The Copenhagen AFASAK Study. Lancet. 1989;1:175-179.

47. Adams HP Jr, Bendixen BH, Kappelle LJ, Biller J, Love BB, Gordon DL, Marsh EE III. Classification of subtype of acute ischemic stroke. Definitions for use in a multicenter clinical trial. TOAST. Trial of Org 10172 in Acute Stroke Treatment. Stroke. 1993;24:35-41.

48. Lee TH, Hsu WC, Chen CJ, Chen ST. Etiologic study of young ischemic stroke in Taiwan. Stroke.
2002;33:1950-1955.

49. Putaala J, Metso AJ, Metso TM, Konkola N, Kraemer Y, Haapaniemi E, Kaste M, Tatlisumak T. Analysis of 1008 consecutive patients aged 15 to 49 with first-ever ischemic stroke: the Helsinki Young Stroke Registry.Stroke. 2009;40:1195-1203.

50. Sheu JJ, Kang JH, Lin HC: Hyperthyroidism and risk of ischemic stroke in young adults: a 5-year follow-up study. Stroke 2010; 41: 961-966.Cardiology 2014;128:51-53. DOI: $\quad 10.1159 / 000357613$. www.karger.com/crd

\section{How to cite this article?}

Dr. Wawhal M, Dr. Mogal V, Dr. Dalvi V, Dr. Sanap S, Dr. Rathi A. Non Atrial Fibrillation related Central Retinal Artery Occlusion (CRAO) in Hyperthyroidism: A Case Report. Int $J$ Med Res Rev 2015;3(1):121-126. doi: 10.17511/ijmrr.2015.i1.21 